\title{
HISTOLOGICAL PROCESSING TECHNIQUES FOR THE STUDY OF DUGESIIDAE DEVELOPMENT (PLATYHELMINTHES, TRICLADIDA, PALUDICOLA)
}

\author{
VARA, D. C. da, LEAL-ZANCHET, A. M. and LIZARDO-DAUDT, H. M. \\ Instituto de Pesquisas de Planárias e Laboratório de Embriologia, Centro de Ciências da Saúde, Universidade do \\ Vale do Rio dos Sinos, Av. Unisinos, 950, São Leopoldo, RS, Brazil \\ Correspondence to: Ana Maria Leal-Zanchet, Centro de Ciências da Saúde, UNISINOS, Av. Unisinos, 950, \\ CEP 93022-000, São Leopoldo, RS, Brazil, e-mail: ipp@ cirrus.unisinos.br \\ Received January 12, 2000 - Accepted April 13, 2000 - Distributed May 31, 2001
}

(With 8 figures)

\begin{abstract}
The objective of the present study was to adapt techniques for the histological processing of Dugesiidae cocoons for the study of embryo development. The cocoons were fixed with formalin, SUSA, Bouin or paraformaldehyde/glutaraldehyde and subsequently embedded in Paraplast or glycol methacrylate (Historesin). Paraplast embedding yielded reasonable results only after the cocoon was perforated or fixed for a prolonged period of time using softening techniques with acid solutions. When the SUSA or Bouin fixative and Historesin embedding techniques were used the results were good for light microscopical analysis. Fixation with paraformaldehyde/glutaraldehyde and glycol methacrylate embedding resulted in better tissue preservation, and did not require prolonged fixation or softening techniques. Thus, we suggest this technique for light microscopical analysis of embryo development in Dugesiidae.
\end{abstract}

Key words: embryo development, techniques, glycol methacrilate, Tricladida.

\section{RESUMO}

Técnicas de processamento histológico para estudos do desenvolvimento embrionário de Dugesiidae (Platyhelminthes, Tricladida, Paludicola)

Este trabalho teve por objetivo adequar técnicas ao processamento histológico de casulos de Dugesiidae para a realização de estudos do desenvolvimento embrionário. Os casulos foram fixados em formol $10 \%$, SUSA, Bouin ou paraformaldeído/glutaraldeído, e, subsequientemente, incluídos em paraplasto ou glicol-metacrilato (Historesin). A inclusão em paraplasto forneceu resultados razoáveis apenas após fixação por tempo prolongado e utilização de técnicas de amolecimento por soluções ácidas ou perfuração do casulo. Utilizando-se fixação em SUSA ou Bouin e inclusão em Historesin, foram obtidos bons resultados para análise ao microscópio óptico. Porém, a fixação com paraformaldeído/glutaraldeído e a inclusão em Historesin resultaram, sob todos os aspectos, em uma melhor preservação dos tecidos, além de dispensar o uso de técnicas demoradas de fixação e amolecimento. Assim, sugerese a utilização dessa técnica para estudos ao microscópio óptico do desenvolvimento embrionário de Dugesiidae.

Palavras-chave: desenvolvimento embrionário, técnicas, glicol-metacrilato, Tricladida.

\section{INTRODUCTION}

Few data are available about the embryo development of freshwater triclads (Le Moigne, 1963). However, morphological and morphogenetic characters concerned with oocyte and yolk cell structure, cleavage patterns and modes of gastrulation have been used to elucidate phylogenetic relationships among the Turbellaria (Thomas, 1986). 
The embryos of triclads have a rigid capsule, the cocoon, which consists of sclerotized and keratinized proteins (Minganti, 1957). This constitution hampers the penetration of fixatives and infiltrating solutions. Thus, we verified that the histological processing of the cocoons should be adapted for light microscopy in order to study the embryo development of Dugesiidae.

\section{MATERIAL AND METHODS}

We used cocoons of Girardia tigrina (Girard, 1850) specimens maintained in the laboratory at a constant temperature of $22^{\circ} \mathrm{C}$. Two embedding techniques were tested: Paraplast and glycol methacrylate (Historesin). All processed material was tested in terms of fixation time, ranging from 2 $\mathrm{h}$ to five days (maximum).

The Paraplast-embedded material was fixed in $10 \%$ formalin, SUSA or Bouin (Michalany, 1980). The cocoons fixed with these solutions were treated with acids commonly used for histology, such as nitric acid, trichloroacetic acid and formic acids (Paulete-Vanrell, 1967). After softening, the cocoons were immersed in sodium sulfate for 24 hours in order to neutralize the action of the acids on the embryonic tissues.

The subsequent steps for histological processing were as follows: dehydration in ethanol absolute and clearing with toluene (Michalany, 1980), or dehydration in increasing concentrations of ethanol and clearing with isopropanol P.A. (Hauser, 1952). Cocoons fixed either in SUSA or in Bouin were also processed for Paraplast embedding by the method of Hauser (1952) without previous acid treatment. In this case these samples were perforated with a needle to facilitate the infiltration of the embedding medium. The Paraplast-embedded material was cut into $7 \mu \mathrm{m}$ thick sections and stained with hematoxylin/eosin (HE).

For glycol methacrylate embedding we used cocoons fixed in paraformaldehyde/glutaraldehyde, SUSA or Bouin. Fixation in paraformaldehyde/ glutaraldehyde was carried out by a variation of the Karnovsky's fixative solution using $4 \%$ aqueous glutaraldehyde and 4\% paraformaldehyde in 0.05 M phosphate buffer ( $\mathrm{pH} 7.2$ ) 1:1 solution (Plattnert, 1975). The material for this procedure was fixed for four hours and then washed in Sörensen's phos- phate buffer (Ruthmann, 1966). The cocoons fixed in SUSA or Bouin were washed in $70 \%$ ethanol. After washing the material was dehydrated with increasing concentrations of ethanol (15-30 min. in each bath), infiltrated with a solution of $50 \mathrm{ml}$ Historesin mixed with $0.5 \mathrm{~g}$ activator in a magnetic stirrer, and embedded in a mixture of infiltration solution and hardening agent. The material embedded in Historesin was cut into $2 \mu \mathrm{m}$ thick sections and stained with toluidine blue (Spurlock et al., 1966) or methylene blue/basic fuchsin (Bennett et al., 1976).

\section{RESULTS}

The histological sections were examined to determine whether the tissues had been properly preserved and to choose the technique that yielded better results. The results are summarized in Table 1 .

The most adequate preservation of Paraplastembedded tissues was obtained with the following methods: (1) fixation in Bouin for five days followed by immersion in $5 \%$ trichloroacetic acid for an equal period of time; and (2) fixation in Bouin or SUSA for five days and later perforation of the cocoon to facilitate Paraplast infiltration.

The results obtained with the two different methods of dehydration and clearing for Paraplast embedding were similar.

Fixation in SUSA or Bouin followed by the Historesin embedding procedure yielded good results for light microscopical analysis. However, fixation in paraformaldehyde/glutaraldehyde and Historesin embedding resulted in better tissue preservation.

\section{DISCUSSION}

In order to analyze the embryonic development of Polycelis nigra (Platyhelminthes: Tricladida), Le Moigne (1963) used fixation in Helly or alcoholic Bouin and paraffin embedding. To facilitate the infiltration of the fixative, the investigator either perforated the cocoons or removed the embryos from the capsule in more advanced stages. However, he obtained poor tissue conservation with the presence of many artifacts due to the rigidity of the cocoon wall. 
TABLE 1

Techniques tested for the histological processing of the cocoon of Girardia tigrina specimens.

\begin{tabular}{|c|c|c|c|c|}
\hline Fixative & $\begin{array}{c}\text { Softening } \\
\text { Technique }\end{array}$ & Clearing & $\begin{array}{l}\text { Embedding } \\
\text { Medium }\end{array}$ & Results \\
\hline $10 \%$ Formalin & $5 \%$ nitric acid & toluene & Paraplast & - \\
\hline $10 \%$ Formalin & $\begin{array}{l}5 \% \text { trichloroacetic } \\
\text { acid }\end{array}$ & toluene & Paraplast & - \\
\hline Bouin & $5 \%$ formic acid & toluene & Paraplast & - \\
\hline Bouin & $\begin{array}{l}5 \% \text { trichloroacetic } \\
\text { acid }\end{array}$ & toluene & Paraplast & +- \\
\hline SUSA* & $* *$ & isopropanol & Paraplast & +- \\
\hline Bouin* & $* *$ & isopropanol & Paraplast & +- \\
\hline SUSA & $* *$ & infiltration solution & glycol methacrylate & + \\
\hline Bouin & $* *$ & infiltration solution & glycol methacrylate & + \\
\hline $\begin{array}{l}\text { Glutaraldehyde/ } \\
\text { paraformaldehyde }\end{array}$ & $* *$ & infiltration solution & glycol methacrylate & ++ \\
\hline
\end{tabular}

$*$ = With perforation

** = Technique not used.

$-=$ Poor tissue preservation, presence of many artifacts.

$+-=$ Reasonable tissue preservation, presence of artifacts.

$+=$ Good tissue preservation.

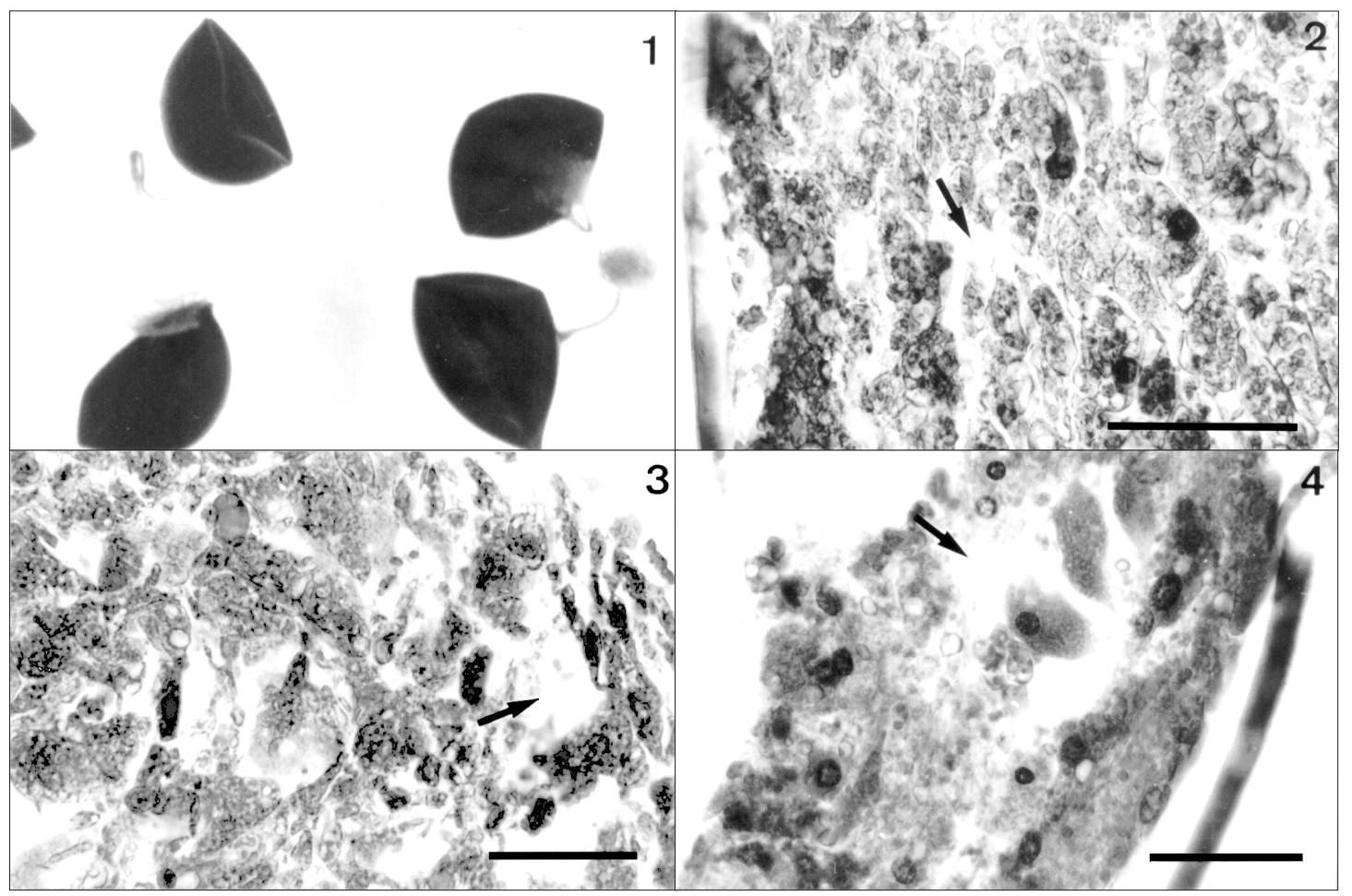

Fig. 1 - Cocoons of Girardia tigrina. Fig. 2 - Histological section $(7 \mu \mathrm{m})$ of material fixed in Bouin's fluid with perforation of the cocoon wall and embedded in Paraplast. The arrow shows artifacts. Scale bar: $50 \mu \mathrm{m}$. Fig. 3 - Histological section $(7 \mu \mathrm{m})$ of material fixed in formaldehyde, treated with formic acid, and embedded in Paraplast. The arrow shows artifacts. Scale bar: $50 \mu \mathrm{m}$. Fig. 4 - Histological section $(7 \mu \mathrm{m})$ of material fixed in formaldehyde, treated with trichloroacetic acid, and embedded in Paraplast. The arrow shows artifacts. Scale bar: $50 \mu \mathrm{m}$. 
In order to analyze the development of $\mathrm{Ma}$ crostomum appendiculatum (Platyhelminthes: Macrostomida), Seilern-Aspang (1957) used fixation of the cocoons in Gelei, dehydration in ethanol P.A., clearing in isopropanol P.A. heated to $60^{\circ} \mathrm{C}$ and embedding in paraffin. He concluded that this technique permitted the utilization of only $60 \%$ of the processed material due to the presence of many artifacts.

In the present study, using techniques similar to the above-cited studies, we observed that only fixation in Bouin for a prolonged period of time or perforation of the cocoon permits reasonable tissue preservation.

The fixative solutions tested in the present study were selected based on the results reported by Silva et al. (1997) for the histological processing of adult specimens of G. tigrina.

However, the greatest difficulty, that was observed in our study, was the softening of the cocoon to permit infiltration of the embedding medium and microtome sectioning. Epoxy resins have been used as embryo tissue embedding media for transmission electron microscopical studies (Le Moigne, 1966; Gremigni \& Domenici, 1975). Although these resins can also be used for light microscopical analysis, glycol methacrylate should be preferentially used for this purpose since it has several advantages, such as lower cost, rapid infiltration and less wear of glass knives.

In the present study, an appropriate infiltration of tricladid embryonic tissues was obtained with glycol methacrylate after fixation in paraformaldehyde/glutaraldehyde. It avoids prolonged periods of fixation and immersion in acid, preventing the occurrence of artifacts.

Thus, we suggest this technique for light microscopical analysis of embryo development in Dugesiidae.

Acknowledgments - The authors are grateful to the laboratory technicians Welcy Hilier Santos for animal maintenance and cocoon collection, Jaqueline Cavalheiro Rodrigues for helping with the preparation of the solutions, and Teresinha Hensel de Oliveira for helping with the photography work.

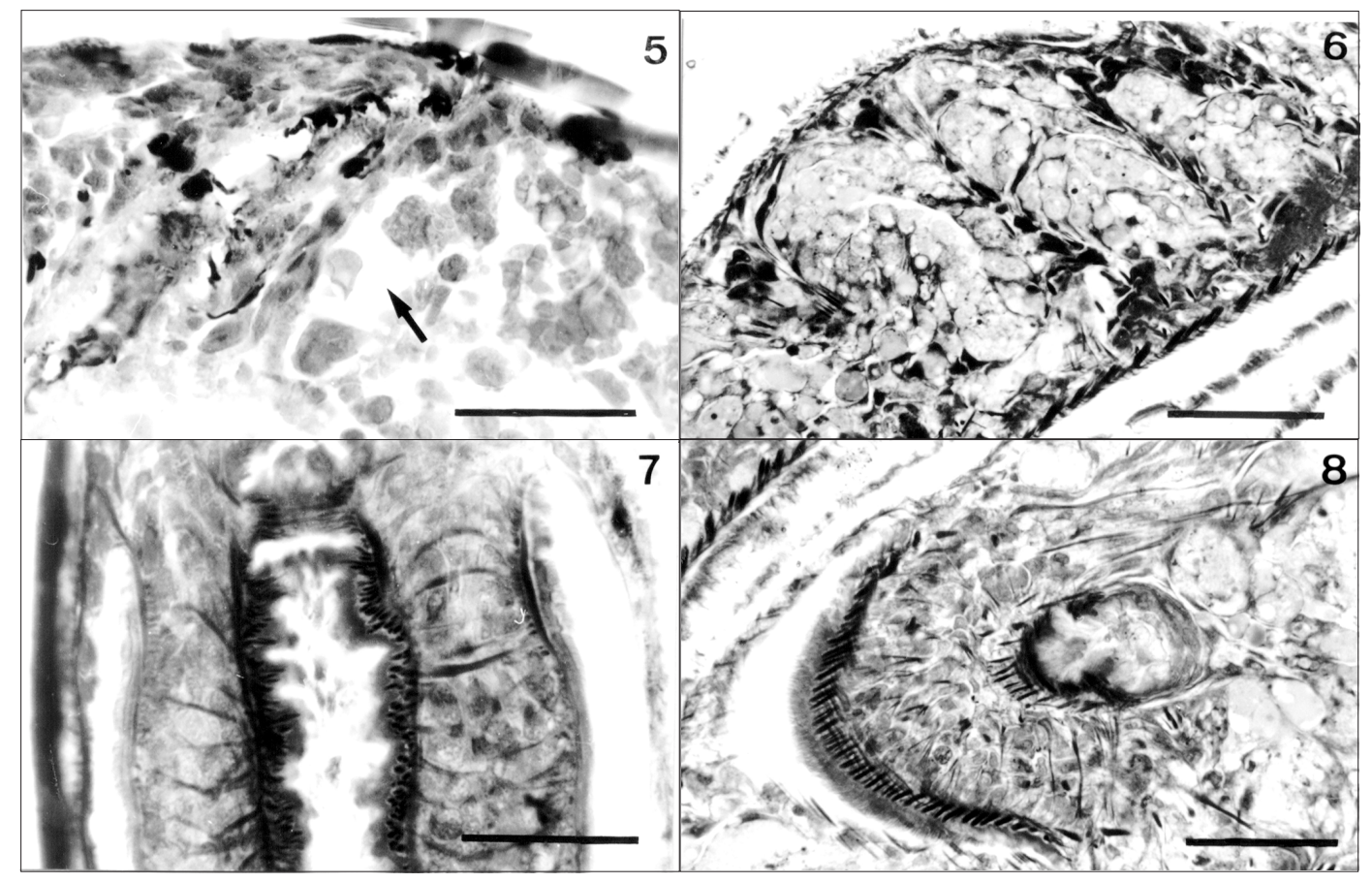

Fig. 5 - Histological section $(7 \mu \mathrm{m})$ of material fixed in Bouin's fluid, treated with trichloroacetic acid, and embedded in Paraplast. The arrow shows artifacts. Scale bar: $50 \mu \mathrm{m}$. Fig. 6 - Histological section $(2 \mu \mathrm{m})$ of material fixed in SUSA and embedded in Historesin. Scale bar: $50 \mu \mathrm{m}$. Fig. 7 - Histological section $(2 \mu \mathrm{m})$ of material fixed in Bouin's fluid and embedded in Historesin. Scale bar: $50 \mu \mathrm{m}$. Fig. 8 - Histological section $(2 \mu \mathrm{m})$ of material fixed in paraformaldehyde/ glutaraldehyde, and embedded in Historesin. Scale bar: $50 \mu \mathrm{m}$. 


\section{REFERENCES}

BENNETT, H. S., WYRICK, A. D., LEE, S. W. \& MCNEIL, J. H., 1976, Science and art in preparing tissues embedded in plastic for light microscopy, with special reference to glycol methacrylate, glass knives and simple stains. Stain Technol., 51(2): 71-97.

GREMIGNI, V. \& DOMENICI, L., 1975, Genesis, composition, and fate of cortical granules in the eggs of Polycelis nigra (Turbellaria, Tricladida). J. Ultrastr. Res., 50: 277-283.

HAUSER, J., 1952, Ausschaltung des Xylols in der histologischen Technik. Mikroskopie, 7(5-6): 208-211.

LE MOIGNE, A., 1963, Étude du développement embrionnaire de Polycelis nigra. Bull. Soc. Zool. France, 88(4): 403-422.

LE MOIGNE, A., 1966, Étude au microscope électronique de cellules d'embryons de Polycelis (Turbellarié, Tricladide), au début de leur développement. C. R. Acad. Sc. Paris, 263: 550-553.

MICHALANY, J., 1980, Técnica histológica em anatomia patológica. Editora Pedagógica e Universitária Ltda., São Paulo, 277p.

MINGANTI, A., 1957, Sulla constituzione chimica degli involucri ovulari negli animali. Boll. Zool., 25: 55-88.
PAULETE-VANRELL, J., 1967, Guia de Técnica Microscópica. Faculdade de Filosofia, Ciências e Letras de São Leopoldo, São Leopoldo, não paginado.

PLATTNERT, N., 1975, Die chemische Fixierung biologischer Objekte für die Eletronenmikroskopie, pp. 3-43. In: G. Schimmel \& W. Vogell (eds.), Methodensammlung der Elektronenmikroskopie. Wissenschaftliche Verlagsgesellschaft $\mathrm{mbH}$, Stuttgart.

RUTHMANN, A., 1966, Methoden der Zellforschung. Franckh'sche Verlagshandlung, Stuttgart, 301p.

SEILERN-ASPANG, F., 1957, Die Entwicklung von Macrostomum appendiculatum (Fabricius). Zool. Jb., Abt. Anat. u. Ontog., 76: 311-330.

SILVA, N. M. S., LEAL-ZANCHET, A. M. \& HAUSER, J., 1997, Analysis of the efficiency of different solutions for the fixation of Girardia tigrina (Turbellaria, Tricladida, Paludicola). Braz. J. Morphol. Sci., 14(2): 271-274.

SPURLOCK, B. O., SKINNER, M. S. \& KATTINE, A. A., 1966, Simple rapid method for staining epoxi-embedded specimens for light microscopy with the polychromatic staining Paragon-1031. Am. J. Clin. Pathol., 46: 252-258.

THOMAS, M. B., 1986, Embryology of the Turbellaria and its phylogenetic significance. Hidrobiologia, 132: 105115. 